\title{
The New Modelling Method in Urban Development: Case Study in Rotterdam
}

\author{
By Hung-Chu Chen * \\ Bauke de Vries ${ }^{\dagger}$ \\ Qi $\mathrm{Han}^{+}$
}

Land-use transition, energy consumption, and temperature fluctuation are the three dominant topics that have been investigated in this research. In the last century, 38 heat waves occurred in Europe, eleven of which were after 1900 and six after 2000 (IPCC, 2008). Local-climate changes due to urbanization are generalized by the urban heat island (UHI), which mainly focuses on the interaction of land use and temperature. However, energy is also an important issue when investigating the sustainable urban development. This research detects correlations between land-use transition, energy consumption, and temperature fluctuation in the Rotterdam area from 1996 till 2014. A series of maps illustrate the relationship of temperature fluctuation and energy consumption. These two variables are linked via land-use maps. From the data set, the spatial parameters, that have a significant effect on the correlation between temperature fluctuation and energy consumption, are estimated. Finally, an equation to describe the dependency of energy consumption to the land use has been built in this paper for the L-E spatial interaction model.

Keywords: Energy consumption, Land use, Rotterdam, Temperature

\section{Introduction}

Climate change is a critical issue of the $21^{\text {st }}$ century (Wilby, 2007; Sanders and Phillipson, 2003). Due to the population growth, the use of land has become more intensive and energy consumption has increased. This phenomenon developed countries has even more serious problems (City of Rotterdam, 2007).

Many researches in UHI focus on the small region surveys (Klok et al., 2012; Stone and Norman, 2006; Doulos et al., 2004) and target on human health and human comfort. However, only a few studies have researched the association between UHI, land use and energy consumption (Hamin and Gurran, 2009; Salamanca et al., 2012; Heusinkveld et al.,2014). The interaction and correlation between urban temperature change, land use planning and the urban energy modelling has been investigated in this project. The previous researches (Zhao et al., 2011; Viegas et al., 2013; Weng, Lu and Schubring, 2004; Emmanuel and Krüger, 2012; Steeneveld et al., 2011; Houet and Pigeon, 2011) declared that the urban morphology has a considerable influence on UHI

\footnotetext{
* PhD Student, Eindhoven University of Technology, The Netherlands.

${ }^{\dagger}$ Professor, Eindhoven University of Technology, The Netherlands.

* Assistant Professor, Eindhoven University of Technology, The Netherlands .
} 
and consequently influences the energy consumption in the city, which leads to land use planning for different functions. The following issues are explored in this project (Chen et al., 2014):

- To assess the changes in city landscape or morphology in terms of adapting to temperature change, especially while considering the UHI issue.

- To reform the urban land use maps that can adapt to UHI with the capacity of reducing the temperature fluctuation and diminishing the energy consumption.

- To investigate broadly surface changes and blueprint changes, which helps to undermine the UHI and the benefits the energy efficiency.

- To provide a decision support simulation tool, which could recommend the optimum land use morphology or balance the adaptation and mitigation strategies.

The previous researches that focused on the urban energy modeling have stated on energy related carbon emission (Yi, et al., 2013), energy potential mapping (Broersma, Fremouw and Dobbelsteen, 2013) and the urban energy balancing model (Middel, et al., 2011; Balogun et al., 2009; Grimmond et al., 2010; Christen and Vogt, 2004; Coutts et al., 2007; Kalanda et al., 1980; Piringer et al., 2007; Mitchell et al., 2008). This research focuses on urban energy modelling. The urban energy modelling is categorized as urban supply modelling, urban demand modelling and urban storage modelling. The energy demand modelling that depends on urban morphology is the main focus point of this research.

\section{Materials and Methods}

\section{Study Area}

Rotterdam $\left(51^{\circ} 55^{\prime} 51^{\prime \prime} \mathrm{N}, 4^{\circ} 28^{\prime} 45^{\prime \prime} \mathrm{E}\right)$, the city in the Netherlands, is the target research area in this project. The Netherlands is a country located in Northwest Europe, which has oceanic climate influenced by the North Sea and Atlantic Ocean. Due to this, the Netherlands has moderate winters and cool summers. Rotterdam is the largest port in Europe, and the second largest city in the Netherlands, with a population of over 600,000 . It is a city in South Holland, located geographically within the Rhine-Meuse-Scheldt river delta at the North Sea (City of Rotterdam, 2013). In this paper, the selected four digital zip code areas, 3011, 3012, 3014, 3015, 3016, 3071, 3072, 3073, 3074, 3081 which are close to the Nieuwe Maas River have been discussed (Figure 1). The selected analysis area has been divided into 4987 cells. Each cell is 50 by 50 square meters. The selected area is 124,600 square meters in total. The ground location is $(91034,433826)$ to $(95435,437927)$. The GIS coordination system 
has been set up as RD (Rijks-Driehoek) system (Dutch geographical service). Further information about the data source and units is listed below:

- Land Use (L): Data Archiving Networked Services (DANS) provides the land use change data in Rotterdam from 1996 to 2010. The future master plan in the Netherlands can be found in guidelines such as Urban Vision Rotterdam 2030 (City of Rotterdam, 2007) and Masterplan Rotterdam Vooruit (Rotterdam Vooruit, 2009), which was published by Gemeente Rotterdam. The land use types have been divided into four types: green land (forest, agricultural land, green house, and green area), water field (water, and natural wet), built up areas (residential area, and industrial area), and open space (railway, open spaces, airport, and road). There are totally 38 types of land used on the collected data, the detailed coding type can be viewed in Table 1. This paper selects the data from 2010 to analyse first step modelling (Figure 2). Figure 3 illustrates the modified cell data of land use inside the File Management Engine (FME).

Table 1. Coding System of Land Use

\begin{tabular}{cclccl}
\hline Group & Code & Land use type & Group & Code & Land use type \\
\hline 1 & 10 & Rail area & 5 & 50 & Greenhouse cultivation \\
& 11 & Road area & & 51 & Other agricultural area \\
& 12 & Airport & 6 & 60 & Forest \\
& 20 & Residential area & & 61 & Natural area, dry \\
& 21 & Retail and bars & & 62 & Natural area, wet \\
& 22 & Public facility & 7 & 70 & Ijsselmeer \\
& 23 & Social \& cultural & & 71 & Closed sea \\
& 24 & Industrial areas & & 72 & Rijn \& Maas \\
3 & 30 & Dump & & 73 & Border lake \\
& 31 & Wreck/storage place & & 74 & Water winning area \\
& 32 & Cemetery & & 75 & Water area for leisure \\
& 33 & Mineral production & & 76 & Enclosed water for mineral \\
& place & & 77 & Oveduction \\
& 34 & Construction area & & 78 & Other water \\
& 35 & Other open space & & Wadden sea \&Eems, Dollard \\
4 & 40 & Park & 8 & 80 & Oosterschelde \\
& 41 & Sport & & 81 & Westerschelde \\
& 42 & Community garden & & 82 & North sea \\
& 43 & Leisure (short stay) & & 83 & Foreign country \\
& 44 & Leisure (long stay) & 9 & 90 &
\end{tabular}

- Energy Consumption (E): Urban cluster from the city of Rotterdam(City of Rotterdam, 2006) provided the annual electricity consumption (kWh), gas consumption $\left(\mathrm{m}^{3}\right)$, and $\mathrm{CO}_{2}$ emission $(\mathrm{kg})$ in a 6 digit zip code, which is separated by commercial and private use from 2008 to 2013 (Figure 1). This paper focuses on urban energy modelling, especially on electricity demand $(\mathrm{kWh})$ and gas consumption $\left(\mathrm{m}^{3}\right)$. When the energy consumption data is protected or there is no data in some industrial and commercial area, then it is presented as value 0 on the map. The values presented in each cell are modified values, which are the summation of electricity consumption or gas 
consumption on commercial and private use divided by the cell area $(50 \mathrm{~m} * 50 \mathrm{~m})$. The electricity and gas consumption data for a longer period might be collected from an energy supplier in Rotterdam (e.g., STEDIN). This paper selects the data from 2010 to analyse the first step modelling (Figure 2). Figure 3 illustrates the modified cell data of the energy consumption inside FME.

- Temperature (T): Royal Netherlands Meteorological Institute (KNMI) is the Netherlands national institute for weather and climate research. KNMI forecasts that the temperature will rise by $1^{\circ} \mathrm{C}$ to $2^{\circ} \mathrm{C}$ in $2015 ; 1.5^{\circ} \mathrm{C}$ and $4.5^{\circ} \mathrm{C}$ in 2100 compared to last century (Klok et al., 2010). With this forecasting, the transition and the trend of the temperature pattern in selected the Dutch city, Rotterdam has been observed. Additionally, the satellite thermal camera image can be purchased from the Waterwatch Company (now eLEAF). The other satellite thermal image can be found on Landsat and MODIS.

-Policy: The main policy in the Netherlands related to climate change, land use, and energy regimes will be analysed in the next step of this project. These policies have been collected from the local government and from EU projects (Notenboom et al., 2012).

Figure 1. Rotterdam Geographical Location, (a) Netherlands, (b) Rotterdam, (c) Selected Area

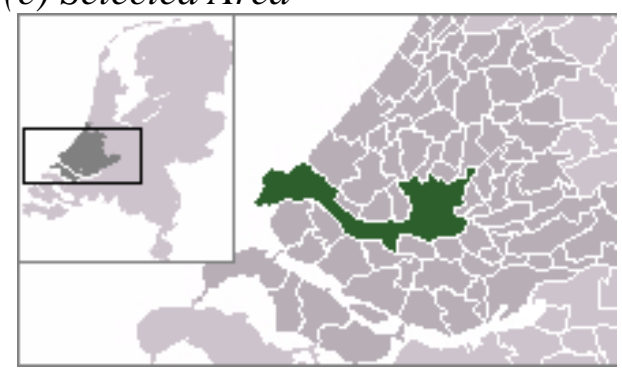

(a)

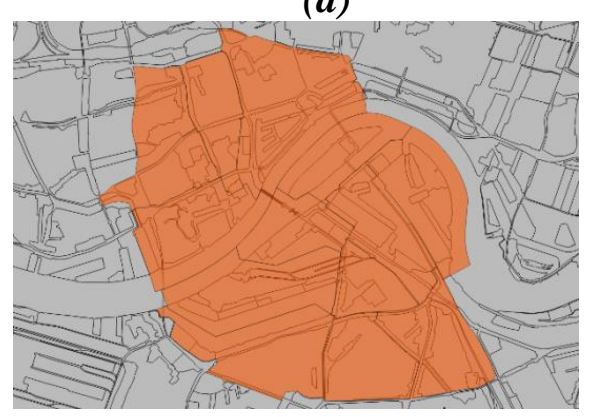

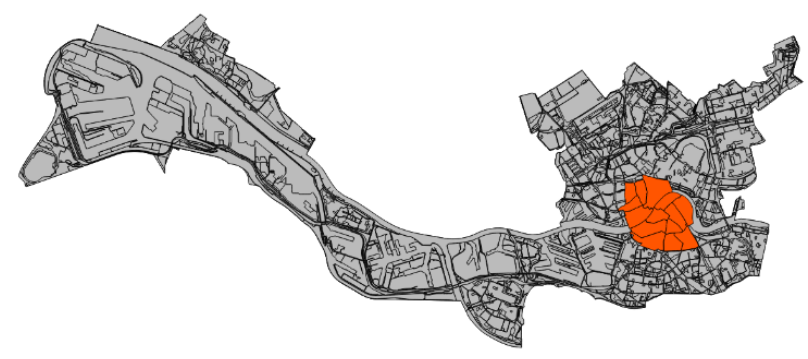

(b)

(c) 
Figure 2. Original Spatial Data, (a) Land Use and (b) Energy Consumption (c) Thermal Map

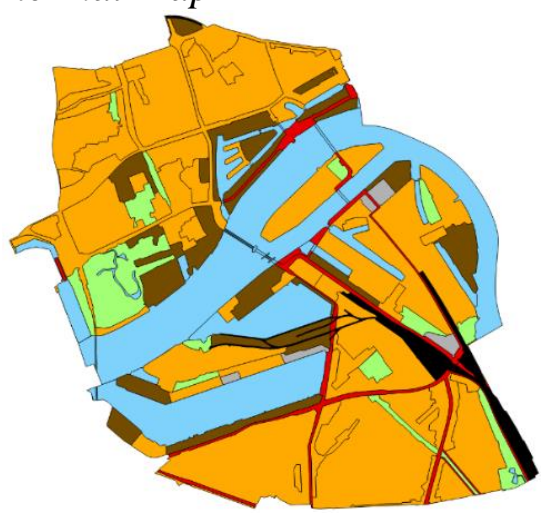

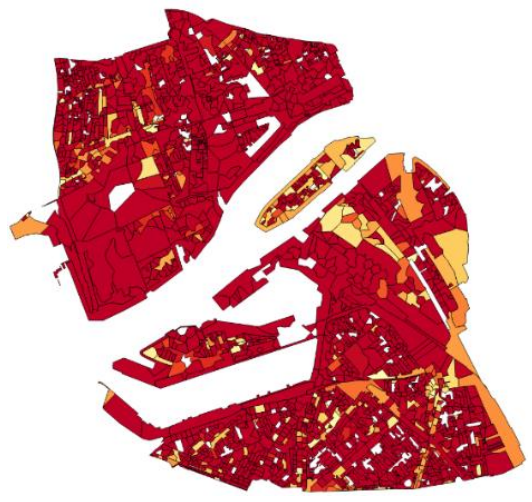

(b) (a)

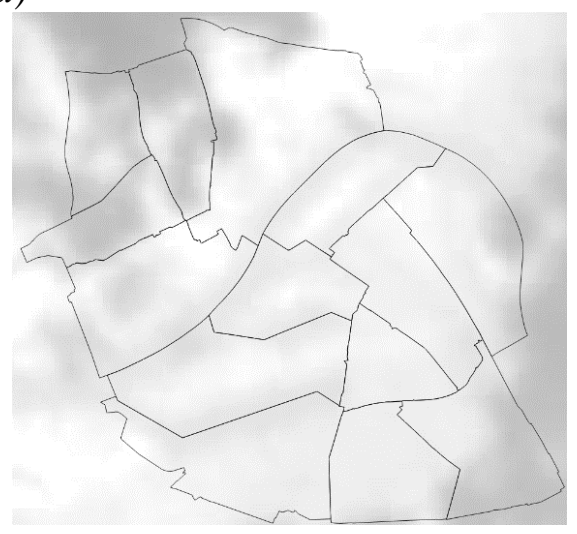

(c)

Figure 3. (a) Land Use and (b) Gas Consumption (c) Electricity Consumption Cells View
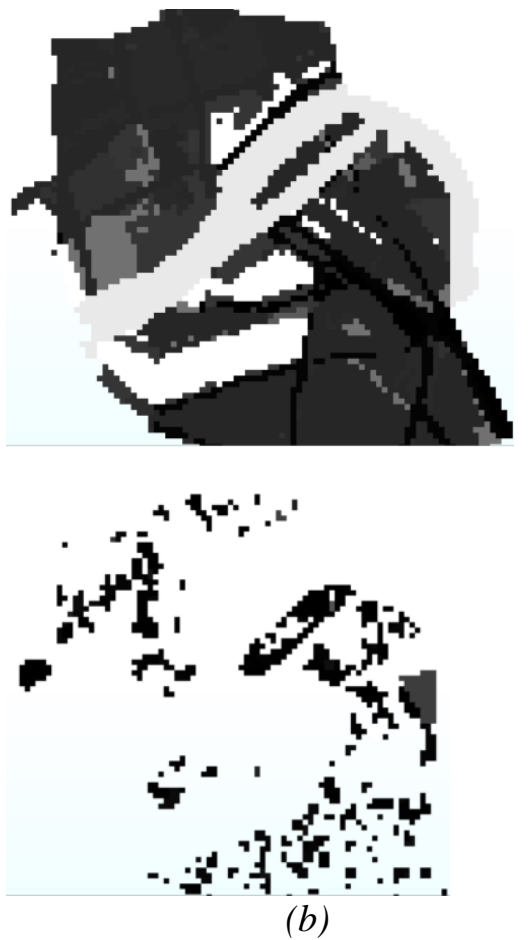

(a)

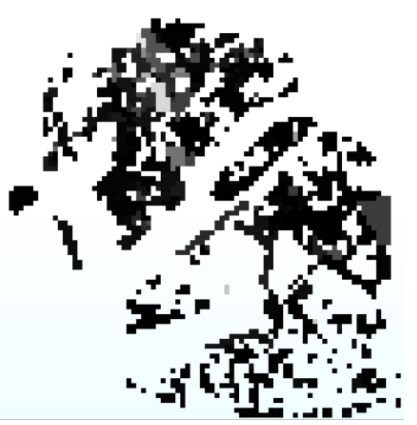

(c) 


\section{Methodology}

Spatial analysis methods include the information entropy theory (Chen et al., 2014; Yi et al., 2013), the geographic information system, the method combined with remote sensing imagery (Myint et al., 2011), the landscape ecology method (Valbuena et al., 2010), and mathematical methods such as the Markov chain modeling and linear programming methods (Bennett et al., 2011). This research uses the statistical method to investigate the correlation between urban energy demand modelling and land use types. This paper proposes the early-stage of this sustainable L-E-T model (Figure 4), which analyses the correlation of land use and energy consumption. There are three types of data: the energy consumption map, the land use map, and the map of temperature, with a duration from 1996 to 2014. The future forecasting maps of energy, land use, and temperature will be built based on the Masterplan of the city. The following platforms have been applied to explore the correlationship between the E-L map, L-T map, and T-E map:

- Cellular automata (CA) platforms like NetLogo for the simulation of spatial interaction,

- GIS platforms like QGIS and ArcGIS for the maps and results visualization,

- System dynamics (SD) platforms, for example VenSim for the forecasting functions.

Figure 4. L-E-T Model Spatial Research Framework

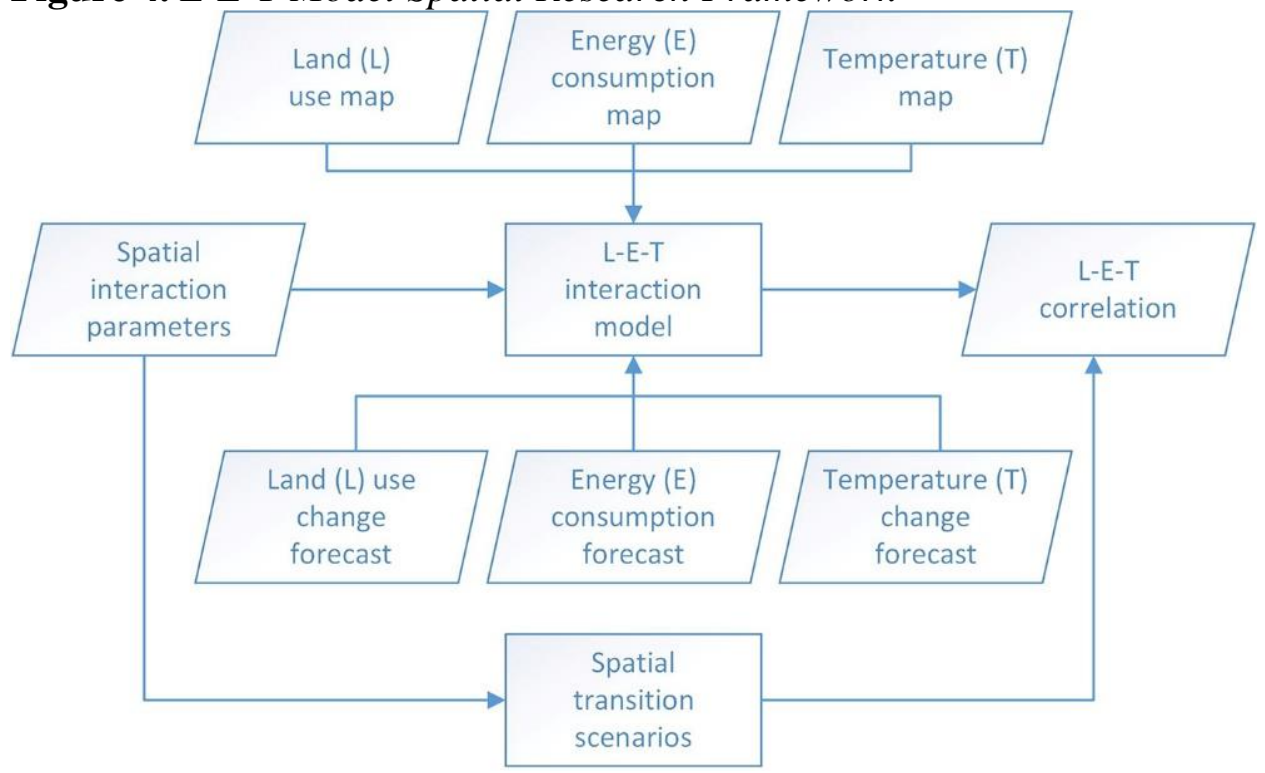

The Decision Support System (DSS) scheme of the L-E-T interaction model is illustrated in Figure 4. Firstly, the data related to land use (L) map, energy consumption (E) map and temperature (T) map have been collected. Next, the L-E-T interaction model will be developed, which will utilize 
detecting the casual relationship between indicators of the land use change, energy consumption, and temperature change. Furthermore, the forecasting of the three sub-models will be built up following the previous researches and integrating with the collected database. The interaction model will be further elaborated for various forecast scenarios. Finally, the detected interactions will be applied to simulate the effect of the potential policies and strategies for different spatial transition scenarios. The local policies and the master plan of Rotterdam city will be investigated. During the model development, the spatial transition scenarios can be used to check the L-E-T interaction effects. Through this working circle, the sustainable interaction model can be adjusted to its optimal condition. In the end, it can be a tool for sustainable land use planning which provides decision support for policy assemblers and urban planners.

This paper presents the early stage development of the L-E-T model. Figure 5 illustrates the L-E-T hypothetical correlation. The land use type is an independent variable which influences energy consumption and temperature. However, there is no algorithm that can clearly state the correlation of central land use types and neighboring land use types. Thus, the represented land useenergy spatial modeling aims to compare the spatial data, finding correlationship of land use and energy consumption, and to build up the equation to describe the correlation.

Figure 5. L-E-T Model Hypothetical Correlation

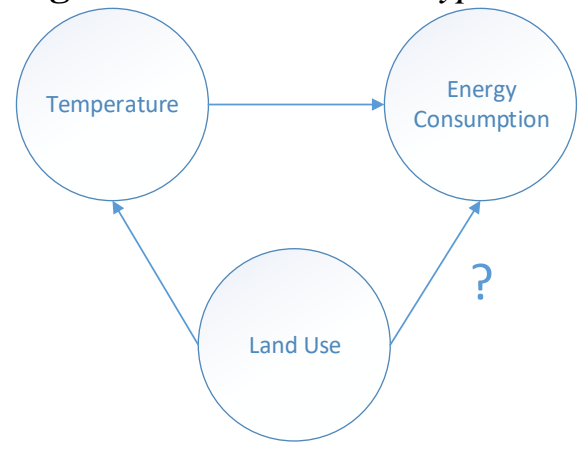

Equation (1) specifies the hypothesis of the urban energy demand model and land use. The multiple linear regression acts as a main method to analyse the correlation between land use and energy demand. The statistical data of different neighbouring land use types has been used in this multiple linear regression model. $\mathrm{y}_{\mathrm{c}}$ is the natural logarithm of energy consumption within the central cell for gas and electricity. $\beta$ means the regression coefficient of the land use. The land use percentage $x$ presents the amount of the land use over the total neighboring cells. In this paper, the software SPSS has been applied to analyze this regression model. 
$y_{c}=x_{c} \beta_{c}+\frac{1}{R} \sum \beta_{\mathrm{n}} x_{n}$

$y_{c}$ : energy consumption of central cell (gas or electricity)

$\beta_{c}$ : energy consumption regression correlation of central land use to central $\beta_{n}$ : ener gy consumption regression correlation of neighboring land use to central $x_{c}$ : central land use percentage in central $x_{n}$ : different neighboring land use percentage

$R$ : distance's $\ln$ of neighbouring cells to central c: central cell n: neighbouring cell

The L-E-T model hypothesizes that land use types will influence neighbouring area's energy consumption. To build up the method in a logical way, the percentage of central and neighbouring land use types are parameters of the L-E-T model. Besides, each $\mathrm{x}, \mathrm{y}$ coordinate represents a cell. The distance of the neighbouring cells to the central cells is also one of the urban morphology parameters. Based on the reviewed paper (Balazs et al., 2009), the hypothetical concentric cell buffering is illustrated in Figure 6 below. The first ring of the neighbouring cell is represented as $\mathrm{N}_{1}$, and the second ring of the neighbouring cell is represented as $\mathrm{N}_{2}$. The central cell's energy demand is calculated as the summation of the central land use regression coefficient product 1 (only one kind of land use in the centre so it is 100\%). Afterwards, the results of central cell's energy demand are added to the product of $1 / \mathrm{R}$ and $\Sigma \beta n X_{n}$. R represents the distance's natural logarithm (ln) between central and neighbouring cell. $\Sigma \beta_{n} X_{n}$ represents the summation of the regression coefficient $\beta_{\mathrm{n}}$ multiplied by the percentage of the neighbouring land uses types $x_{n}$ (e.g. water $30 \%$, green $20 \%$, residential $50 \%$ ). To calculate the percentage of land use in ring one $\left(\mathrm{N}_{1}\right)$, the amount of land used cells are divided by 8 (cells amount in the first neighbouring ring), which equals $(n+2)^{2}-n^{2}$. Following the same rule, the value of land use cells is divided by 16 to calculate the percentage of land use in ring two $\left(\mathrm{N}_{2}\right)$.

Figure 6. Hypothetical Buffer Cell

\begin{tabular}{|l|l|l|l|l|}
\hline $\mathrm{N}_{2}$ & $\mathrm{~N}_{2}$ & $\mathrm{~N}_{2}$ & $\mathrm{~N}_{2}$ & $\mathrm{~N}_{2}$ \\
\hline $\mathrm{N}_{2}$ & $\mathrm{~N}_{1}$ & $\mathrm{~N}_{1}$ & $\mathrm{~N}_{1}$ & $\mathrm{~N}_{2}$ \\
\hline $\mathrm{N}_{2}$ & $\mathrm{~N}_{1}$ & $\mathrm{C}$ & $\mathrm{N}_{1}$ & $\mathrm{~N}_{2}$ \\
\hline $\mathrm{N}_{2}$ & $\mathrm{~N}_{1}$ & $\mathrm{~N}_{1}$ & $\mathrm{~N}_{1}$ & $\mathrm{~N}_{2}$ \\
\hline $\mathrm{N}_{2}$ & $\mathrm{~N}_{2}$ & $\mathrm{~N}_{2}$ & $\mathrm{~N}_{2}$ & $\mathrm{~N}_{2}$ \\
\hline
\end{tabular}


Figure 7. Percentage of Land Use Types in Selected Area

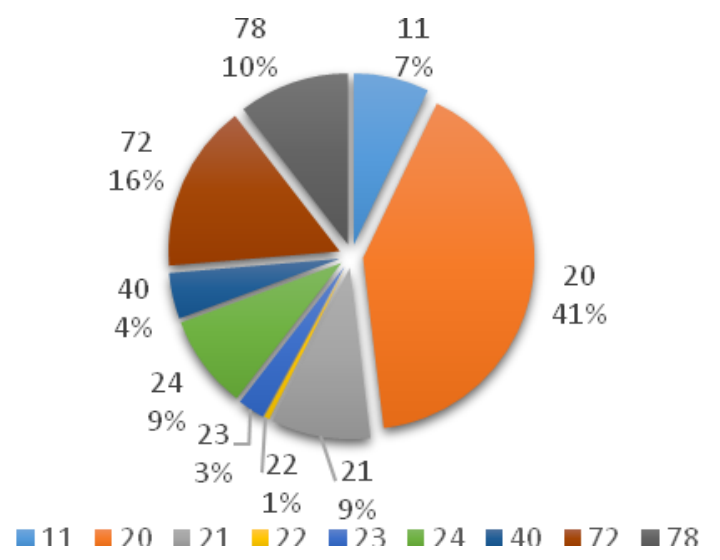

The different land use types and their percentage within the selected area are presented in Figure 7. Within the selected analysis area, the largest proportion is the land use for residential housing (code: 20), which accounts for 1988 cells. This is followed by water area (code: 72 and 78), which accounts for 769 and 508 cells. The third largest group are the retailing buildings (code: 21) which accounts for 454 cells. The hypothesis of this paper assumes that the land use type of neighbouring areas might influence energy consumption of central cells. The basic simulation is based on the $3 * 3$ gridding system. The influence of the middle cell which is surrounded by different neighbouring cell formations (Figure 8) has been investigated statistically. Table 1 presents the meaning of the land use type coding. To analyse the hypothetical correlation of land use and energy demand, this paper compares the central cell with different percentages of neighbouring land use types. For example, the same central cell land use type might have different energy consumption due to neighbouring cell land use type variations. For example, the percentage of the green area surrounding cell R1 might cause less energy consumption compared to another cell (R2) surrounded by the water body.

Figure 8. Energy Consumption of $R_{1}$ and $R_{2}$

\begin{tabular}{|c|c|c|}
\hline$G$ & $G$ & $G$ \\
\hline$G$ & $R_{1}$ & $G$ \\
\hline$G$ & $G$ & $G$ \\
\hline
\end{tabular}

\begin{tabular}{|c|c|c|}
\hline $\mathrm{W}$ & $\mathrm{W}$ & $\mathrm{W}$ \\
\hline $\mathrm{W}$ & $\mathrm{R}_{2}$ & $\mathrm{~W}$ \\
\hline $\mathrm{W}$ & $\mathrm{W}$ & $\mathrm{W}$ \\
\hline
\end{tabular}

\section{Results}

Regression Model of Land Use and Gas Consumption

The data of the gas consumption is in the unit of the cubic meter originally. The gas consumption value ranges from $0.01 \mathrm{~m}^{3}$ to $448.25 \mathrm{~m}^{3}$ within 
the selected area. The natural logarithm value (LN) of the gas consumption data has been implemented in Equation (1) for narrowing down the range of the data. The LN (gas) value becomes -4.59 to 6.10 . In this model, the independent variables are central and neighbouring land use cells, and the dependent variable is LN (gas). The multiple linear regression results for gas consumption, influenced by different land use, are presented in Table 2. Rsquared for this regression model is 0.201 from SPSS. Table 2 shows the value of the regression coefficient of different land use types to gas consumption. The output of the multi linear regression analysis in SPSS shows that for models with dependent variable LN (gas), the following variables (C10, C11, $\mathrm{C} 20, \mathrm{C} 21, \mathrm{C} 22, \mathrm{C} 23, \mathrm{C} 24, \mathrm{C} 40, \mathrm{C} 72$, and C78) are constants or have missing correlations for all the central cells. They have been neglected from this analysis. Therefore, the regression coefficient for the gas consumption for the central cell $\left(\beta_{1}\right)$ in different land use has no regression coefficient. It might be due to the low impact of the land use of gas consumption and the fact that a few gas appliances are used in this selected area. Other than that, the missing coefficient results might be caused by a high percentage of missing gas consumption data. Within the selected area, only $15.68 \%$ (782 cells over 4987 cells) of cells have data to be analysed its coefficient correlation within the selected area (4 digital zip code: 3011, 3012, 3014, 3015, 3016, 3071, 3072, $3073,3074$, and 3081$)$. For the neighbouring cell $\left(\boldsymbol{\beta}_{2}\right)$, the land use has a positive coefficient for gas consumption in the case of land use code, 10 (railway), 78 (other water), and 23 (social cultural facility). In contrast, the land use has a negative coefficient for the gas consumption in the case of land use codes, 21 (retailing area), 22 (public facility), 72 (Rijn \& Maas), 40 (park), 20 (residential area), 24 (industrial area), and 11 (road). Figure 9 visualizes the comparison of the regression coefficient between different land use types.

Table 2. Regression Coefficient for Gas Consumption in Different Land Use

\begin{tabular}{cccc}
\hline Land use & code & $\boldsymbol{\beta}_{\mathbf{1}}$ & $\boldsymbol{\beta}_{\mathbf{2}}$ \\
\hline Railway & 10 & -- & 3.236 \\
Road area & 11 & -- & -0.049 \\
Residential area & 20 & -- & -0.844 \\
Retail and bars & 21 & -- & -7.806 \\
Public facility & 22 & -- & -4.028 \\
Social cultural facility & 23 & -- & 2.340 \\
Industrial area & 24 & -- & -0.794 \\
Park & 40 & -- & -1.923 \\
Rijn \& Maas & 72 & -- & -2.502 \\
Other water & 78 & -- & 3.236 \\
\hline
\end{tabular}


Figure 9. Regression Coefficient for Gas Consumption with Land Use

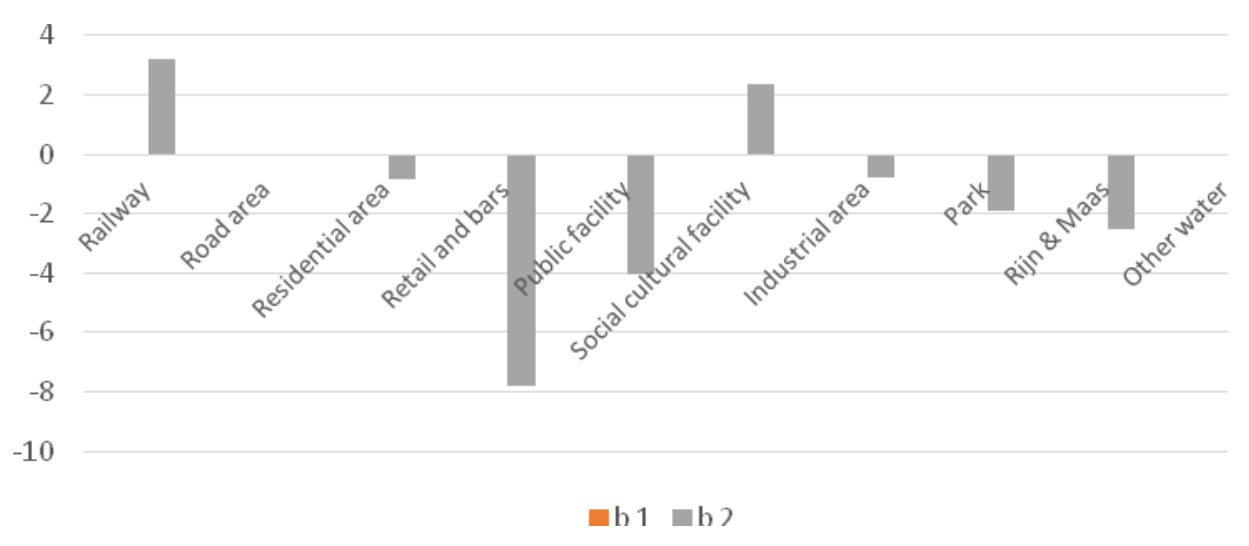

\section{Regression Model of Land Use and Electricity Consumption}

The data of the electricity consumption is expressed by the unit of kilowatt hour $(\mathrm{kWh})$. The electricity consumption value ranges from $0.54 \mathrm{kWh}$ to $1252.46 \mathrm{kWh}$ within the selected area. The natural logarithm value of the electricity consumption data is implemented in Equation (1). The LN (electricity) value becomes -0.62 to 7.13 . In this model, the independent variables are central and neighbouring land use cells, and the dependent variable is LN (electricity). The multiple linear regression for the gas consumption for different land use is presented in Table 3. R-squared for this regression model using SPSS is 0.256. Table 3 shows the value of the regression coefficient of different land use types to the electricity consumption. For the central cell $\left(\beta_{1}\right)$, the regression coefficient for electricity consumption has a positive coefficient in case of code 10 (railway), 22 (public facility), 11(road), 21 (retailing area), 24 (industrial area), and 20 (residential area). In contrast, the regression coefficient for electricity consumption has a negative coefficient in the case of land use code 23 (social cultural facility), 78 (other water), 72 (Rijn \& Maas), 40 (park). For the neighbouring cell $\left(\boldsymbol{\beta}_{2}\right)$, the regression coefficient for electricity consumption has a positive coefficient in the case of land use code, 21(retailing area), 20 (residential area), 23 (social cultural facility), 22 (public facility), 10 (railway), and 78 (other water). In contrast, the regression coefficient for electricity consumption has a negative coefficient in the case of land use code, 72 (Rijn \& Maas), 24 (industrial area), 40 (park), and 11 (road). Figure 10 visualizes the comparison of the regression coefficient between different land use types. 
Table 3. Regression Coefficient for Electricity Consumption in Different Land Use

\begin{tabular}{cccc}
\hline Land use & code & $\boldsymbol{\beta}_{\mathbf{1}}$ & $\boldsymbol{\beta}_{\mathbf{2}}$ \\
\hline Railway & 10 & 1.379 & 1.011 \\
Road area & 11 & 0.443 & -0.058 \\
Residential area & 20 & 0.023 & 2.263 \\
Retail and bars & 21 & 0.147 & 3.036 \\
Public facility & 22 & 0.814 & 1.543 \\
Social cultural facility & 23 & -0.280 & 1.889 \\
Industrial area & 24 & 0.123 & -0.445 \\
Park & 40 & -0.152 & -0.437 \\
Rijn \& Maas & 72 & -0.219 & -0.447 \\
Other water & 78 & -0.256 & 1.011 \\
\hline
\end{tabular}

Figure 10. Regression Coefficient for Electricity Consumption with Land Use

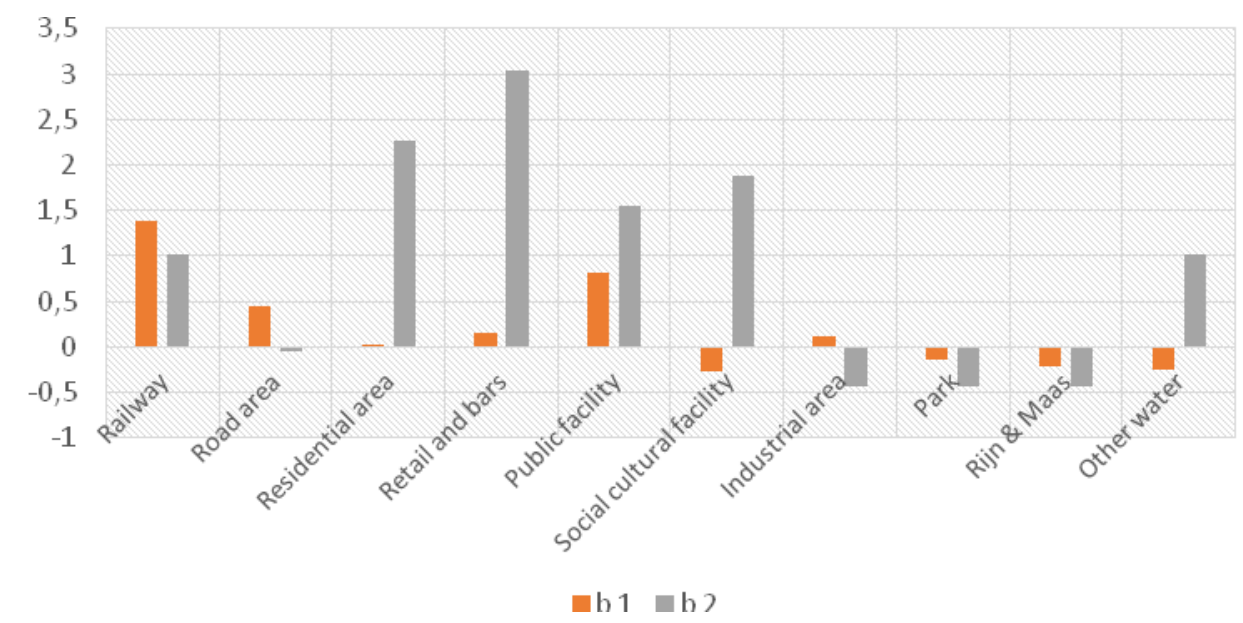

\section{Discussion and Conclusions}

Based on the regression result, the correlation of land use and energy demand can be concluded in two parts: (1) the correlation of land use and gas consumption and (2) the correlation of land use and electricity consumption. For the correlation of land use and gas consumption, it is important to mention that the influence of central cells has been neglected when doing the regression modelling in SPSS. While looking at the neighbouring cell's influence, the retailing buildings and public facilities have a negative influence to the gas demand. In contrast, when a central cell is surrounded by the water area and railway, it tends to have higher gas consumption. This result is under the original expectations, i.e. energy consumption increases in case of lower building density. Conversely, positive effects of social cultural facilities might be due to insufficient data, and will be investigated further. 
The correlation of land use and electricity consumption, is more consistent than the correlation of land use and gas consumption. When a place is surrounded by the railway, residential, retailing and bars, social and cultural facility, and public facility, it has a higher electricity demand. Whereas, if the nearby areas are park, water, and industrial areas, the central land will consume less electricity. This result gives the base for further research, but this effect might cause the reduction of the cooling load for buildings in the case of cutting down building density.

This paper proposes an energy and land use correlation model for a delta city with a moderate climate. There are some limitations and other influence parameters that will be considered in the next stage of the research. The land use -energy consumption correlation can be analysed more regarding the following aspects: human impact, building types, and geographical environment. For the human impact, the density of the human living within the post code area will be included. Building height and building type are also vital parameters for the heating and cooling energy. As for the climate concern, this model is tested in the Netherlands, which is located in Northwest Europe and has temperate maritime climate. Accordingly, if this model is used in the other geographical locations or in the other climate zones, the case studies for this LE-T model are necessary. Finally, energy consumption data is currently based on yearly averages but seasonal changes of cooling and heating load that are influenced by neighbouring land use might reveal profound differences between land use types.

\section{Acknowledgments}

This research is supported and supervised by the Eindhoven University of Technology, Faculty of the Built Environment, Design Decision Supporting System (DDSS) group in the Netherlands.

\section{References}

Balazs, B. et al., 2009. Simulation of the mean urban heat island using 2D surface parameters: empirical modelling, verification and extension. Meteological Applications, Volume 16, pp. 275-287.

Balogun, A. A. et al., 2009. Surface energy balance measurements above an exurban residential neighborhood of Kansas City, Missouri. Boundary-Layer Meteorology, Volume 133, pp. 299-231.

Bennett, D. A., Tang, W. and Wang, S., 2011. Toward an understanding of provenance in complex land use dynamics. Journal of Land Use Science, 6(2-3), pp. 211-230.

Broersma, S., Fremouw, M. and Dobbelsteen, A., 2013. Energy potential mapping: visualising energy characteristics for the exergetic optimisation of the built environment. Entropy, Volume 15, pp. 490-506. 
Chen, H., Vries, B. d. and Han, Q., 2014. Spatial interaction between land use, energy consumption and temperature on the city scale. Delft, Geodesign Summit Europe 2014.

Christen, A. and Vogt, R., 2004. Energy and radiation balance of a central European city. International Journal of Climatology, Volume 24, pp. 1395-1421.

City of Rotterdam, 2006. Planoloog duurzame stedelijke ontwikkeling en GIS, Cluster Stadsontwikkeling, Gemeente Rotterdam [Sustainable urban development and GIS cluster planning of Rotterdam], Rotterdam: City of Rotterdam.

City of Rotterdam, 2007. Stadsvisie Rotterdam 2030 [Urban Vision Rotterdam 2030], Rotterdam: Gemeente Rotterdam.

City of Rotterdam, 2013. Connecting Delta Cities. [Online] Available at: http://www. deltacities.com [Accessed 2013].

Coutts, A. M., Beringer, J. and Tapper, N. J., 2007. Impact of increasing urban density on local climate: Spatial and temporal variations in the surface energy balance in Melbourne, Australia. Journal of Applied Meteorology Climatology. Journal of Applied Meteorology Climatology, Volume 46, pp. 477-493.

Doulos, L., Santamouris, M. and Livada, I., 2004. Passive cooling of outdoor urban spaces. The role of materials. Solar Energy, Volume 77, pp. 231-249.

Emmanuel, R. and Krüger, E., 2012. Urban heat ssland and its Impact on climate change resilience in a shrinking city: The case of Glasgow, UK.. Building and Environment, Volume 53, pp. 137-149.

Gemeente Rotterdam, 2009. Rotterdam Vooruit, Rotterdam: Gemeente Rotterdam.

Grimmond, C. S. B. et al., 2010. The international urban energy balance models comparison project: First results from phase 1.. Journal of Applied Meteorology Climatology, 49(Feb 2010), pp. 1268-1292.

Hamin, E. and Gurran, N., 2009. Urban form and climate change: Balancing adaption and mitigation in the U.S. and Australia. Habitat International, Volume 33, pp. 238-245.

Heusinkveld, B. G., Steeneveld, G. J., van Hove, L. W. A, Jacobs, C. M. J., 2014. Spatial variability of the Rotterdam urban heat island as influenced by urban land use. Journal of Geographical Research: Atmospheres, pp. 677-692.

Houet, T. and Pigeon, G., 2011. Mapping urban climate zones and quantifying climate behaviors-an application on Toulouse urban area (France).. Environmental pollution, Volume 159, pp. 2180-2192.

IPCC, 2008. Climate Change 2007 Synthesis Report, Geneva: Intergovernmental Panel on Climate Change.

Kalanda, B. D., Oke, T. R. and Spittlehouse, D. L., 1980. Suburban energy balance estimates for Vancouver B. C., using Bowen ratio-energy balance approach. Journal of Applied Meteorology, Volume 19, pp. 545-567.

Klok, L. et al., 2010. Ruimtelijke verdeling en oorzaken van het hitte-eilandeffect [Spatial distribution and causes of the heat island effect], Rotterdam: National Research Programme Knowledge for Climate.

Klok, L., Zwart, S., Verhagen, H. and Mauri, E., 2012. The surface heat island of Rotterdam and its relationship with urban surface characteristics. Resources, Conservation and Recycling, Volume 64, pp. 23-29.

Middel, A. et al., 2011. Land cover, climate, and the summer surface energy balance in Phoenix, AZ, and Portland, OR. International Journal of Climatology, Volume 32, pp. 2020-2032.

Mitchell, V. G., Cleugh, H. A., Grimmond, C. S. B. and Xu, J., 2008. Linking urban water balance and energy balance models to analyze urban design options. Hydrological Processes, Volume 22, pp. 2891-2900. 
Myint, S. W. et al., 2011. Per-pixel versus object-based classification of urban land cover extraction using high spatial resolution imagery. Remote Sensing of Environment, Volume 115, pp. 1145-1161.

Notenboom, J., Boot, P., Koelemeijer, R. and Ros, J., 2012. Climate and Energy Roadmaps towards 2050 in north-western Europe, Den Haag: PBL Netherlands Environmental Assessment Agency.

Piringer, M. et al., 2007. The surface energy balance and the mixing height in urban areas: Activities and recommendations of COST-Action 715. Boundary-Layer Meteorology, Volume 124, pp. 3-24.

Salamanca, F., Martilli, A. and Yagüe, C., 2012. A numerical study of the Urban Heat Island over Madrid during the DESIREX (2008) campaign with WRF and an evaluation of simple mitigation strategies. International Journal of Climatology, Volume 32, pp. 2372-2386.

Sanders, C. H. and Phillipson, M., 2003. UK adaptation strategy and technical measures: the impacts of climate change on buildings. Building Research \& Information, 31(3-4), pp. 210-221.

Steeneveld, G. J. et al., 2011. Quantifying urban heat island effects and human comfort for cities of variable size and urban morphology in the Netherlands. Journal of Geophysical Researc, 116(D20129), pp. 1-14.

Stone, B. and Norman, J. M., 2006. Land use planning and surface heat island formation: A parcel-based radiation flux approach. Atmospheric Environment, Volume 40, pp. 3561-3573.

Valbuena, D., Verburg, P. H., Bregt, A. K. and Ligtenberg, A., 2010. An agent- based approach to model land-use change at a regional scale. Landscape ecology, Volume 25, pp. 185-199.

Viegas, V. et al., 2013. Urban land planning: The role of a Master Plan in influencing local temperatures. Cities, Volume 35, pp. 1-13.

Weng, Q., Lu, D. and Schubring, J., 2004. Estimation of land surface temperaturevegetation abundance relationship for urban heat island studies. Remote Sensing of Environment, Volume 89, pp. 467-483.

Wilby, R. L., 2007. A review of climate change impacts on the built environment. Built Environment, 33(1), pp. 31-35.

Yi, H., Bin, X. and Lei, Y., 2013. Relationship study on land use spatial distribution structure and energy-related carbon emission intensity in different land use types of Guangdong, China, 1996-2008. The Scientific World Journal, Volume 309680, pp. $1-15$.

Zhao, C., Fu, G., Liu, X. and Fu, F., 2011. Urban planning indicators, morphology and climate Indicators: A case study for a North-South transect of Beijing, China. Building and Environment, Volume 46, pp. 1174-1183. 
